28. Ford, E. S., Capewell, S. (2011). Proportion of the Decline in Cardiovascular Mortality Disease due to Prevention Versus Treatment: Public Health Versus Clinical Care. Annual Review of Public Health, 32 (1), 5-22. doi: http://doi.org/10.1146/annurevpublhealth-031210-101211

Received date 18.11.2019

Accepted date 16.12.2019

Published date 30.12.2019

Bobokalo Serhii, Senior Laboratory Assistant, Department of Cosmetology and Aromatology, National University of Pharmacy, Pushkinska str., 53, Kharkiv, Ukraine, 61002

E-mail: bobo7sv@gmail.com

Lyudmila Almakaieva, Doctor of Pharmaceutical Sciences, Professor, Department of Cosmetology and Aromatology, National University of Pharmacy, Pushkinska str., 53, Kharkiv, Ukraine, 61002

E-mail: almakaeva@ukr.net

Hanna Panfilova, Doctor of Pharmaceutical Sciences, Professor, Department of Organization and Economics of Pharmacy, National University of Pharmacy, Pushkinska str., 53, Kharkiv, Ukraine, 61002

E-mail: panf-al@ukr.net

Oksana Tsurikova, PhD, Assistant, Department Quality Management, National University of Pharmacy, Pushkinska str., 53, Kharkiv, Ukraine, 61002

E-mail: zurikova2008@gmail.com

UDC 547.655.6

DOI: 10.15587/2519-4852.2019.188127

\title{
PRIMARY SCREENING OF THE BIOLOGICAL ACTIVITY OF HETEROCYCLIC AMI- NODERIVATIVES OF 2,3-DICHLORO-1,4-NAPHTOQUINONE
}

\section{N. Polish, O. Voitsakhivska, N. Marintsova, L. Zhurakhivska, V. Novikov, S. Bohza}

Мета. Провести дослідження антимікробної та фунгіцидної активностей амінопіразольних похідних 2,3-дихлоро-1,4-нафтохінону та спрогнозувати їхню гостру токсичність.

Матеріали та методи дослідження. Протимікробну активність гетероциклічних амінопохідних нафтохінону 3a-d вивчали шляхом дифузї речовини в агар на твердому поживному середовищі та методом серійних розведень. Гостру токсичність для гризунів визначали методом моделювання QSAR, реалізованим в програмному забезпеченні GUSAR .

Результати. У роботі досліджено антимікробну та фунгіщидну активності нових гетерочиклічних амінопохідних нафтохінону, а також проведено визначення їх іп silico гострої токсичності для шурів за чотирма типами введення субстаниії.

Висновки. Дослідження амінопіразольних похідних нафтохінону дозволило виявити сполуки, які проявляють високу антимікробну активність по відношенню до тест-культури Candida tenuis, a caме: 2-хлоро-3-((1-метил-1Н-піразол-4-іл)аміно)нафтален-1,4-діон 3 а та 2-хлоро-3-((1-метил-1Н-піразол-3іл)аміно)нафтален-1,4-діон 3b. Встановлено, щзо усі синтезовані сполуки проявляють вибіркову бактеpio- $і$ фунгістатичну активності. Визначено методом QSAR нетоксичну сполуку 3 с при внутрішньочеревному шляху введення, а також нетоксичну сполуку $3 \boldsymbol{d}$ при підшкірному шляху введення

Ключові слова: амінопіразолопохідні 2,3-дихлоро-1,4-нафтохінону, первинний біологічний скринінг, програма GUSAR

Copyright (C) 2019, N. Polish, O. Voitsakhivska, N. Marintsova, L. Zhurakhivska, V. Novikov, S. Bohza This is an open access article under the CC BY license (http://creativecommons.org/licenses/by/4.0).

\section{Introduction}

Due to the increasing resistance of microorganisms to existing antimicrobial and fungicidal preparations, it is of great relevance to search for new biologically active compounds that could be used in the future for the production of low-toxic, microbial resistant drugs.
That is why heterocyclic amino derivatives of naphthoquinone, which have a wide range of pharmacological activity, in particular, antibacterial [1,2] antifungal [3], anticancer [4, 5], antiviral, anti-inflammatory and regenerating [6], occupy an important place among development of new drug substances. 
The priority for today is the creation of new highly effective, low-toxic, antibacterial drugs as opposed to existing low-active ones. That is why research of new objects containing quinone and pyrazole fragments is an urgent task today.

Many sources of naphthoquinone derivatives that make up the class of natural compounds are listed in the literature: pigments, antibiotics, vitamins, coenzymes [7-9]. Synthetic naphthoquinone compounds are the basis of antibacterial, antifungal, antitumor and antimalarial agents $[1,10,11]$. It has been reported that some heterocyclic amino derivatives of naphthoquinone have antifungal activity [3]. Synthetic thiol derivatives containing 1,4-naphthoquinone have

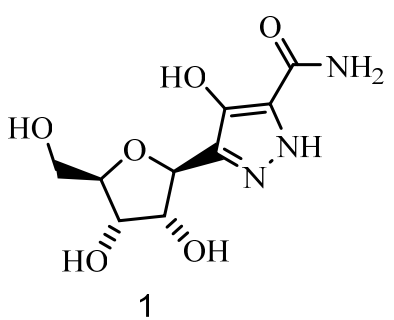

Pyrazofurin<smiles>Nc1ncnc2c(C3OC(CO)[C@@H](O)[C@H]3O)n[nH]c12</smiles>

Formicin been reported as potent antimicrobial and anticancer agents $[2,10]$. However, the toxicity of naphthoquinone compared to antibacterial activity often prevents their use as drugs for the treatment of infectious diseases $[12,13]$.

It is also known that aminopyrazole derivatives are a component of effective drugs [14, 15]. Among them, a rare compound for the pyrazoles is the nucleoside antibiotic Pyrazofurin (1). Also noteworthy is the broad-spectrum lantibiotic Formicin (2) isolated from Bacillus paralicheniformis APC 1576. Effective nonsteroidal anti-inflammatory drugs such as Celecoxib (3) and Butadione (Phenylbutazone) (4) also should be mentioned $[16,17,20]$.<smiles>CCCCC1C(=O)N(c2ccccc2)N(c2ccccc2)C1=O</smiles>

Celecoxib Phenylbutazone
The introduction of an aminopyrazole fragments likely reduces toxicity and broadens the biological activity spectrum of the compounds.

The aim of our study is the primary screening of the biological activity of aminopyrazole naphthoquinone derivatives and in silico the determination of their acute toxicity in rats for rats by four types of substance administration.

\section{Planning (methodology) of research}

The search for new antimicrobial and fungicidal agents is one of the important tasks of scientists of the present day, which are solved by the synthesis of new biologically active molecules [20].

To achieve this aim, the following tasks were set:

1) determine the biological activity of the first time synthesized compounds;

2) determine acute toxicity to rodents by the QSAR simulation method.

The following test strains were used for primary screening of biological activity carried out in accordance with WHO guidelines [18]: Escherichia coli, Staphylococcus aureus, Mycobacterium luteum and fungi: Candida tenuis, Aspergillus niger. The inoculum suspension was prepared using a Densi-La-Meter apparatus (manu- factured by PLIVALachema, Czech Republic; wavelength $540 \mathrm{~nm}$ ).

The suspension was prepared according to the device manual and information sheet No. 163-2006 "Standardization of preparation of microbial suspensions" (Kyiv) on innovations in health care system. The inoculum density was 109 cells (spores) / $1 \mathrm{ml}$ compared to the McFarland Standard [19]. For antimicrobial evaluation we used MullerHinton agar. Antibacterial activity was assessed by measuring the zones of inhibition of the corresponding microorganism and compared with the zones of the reference preparations Nystatin (antimicrobial) and Vancomycin (fungicidal).

Acute rodent toxicity was determined by the QSAR simulation method using a free, accessible web service http://www.pharmaexpert.com/GUSAR/AcuToxPredict/).

\section{Materials and methods}

Due to the special value of naphthoquinonesand aminopyrazoles, the synthesis and research of new compounds containing both the pyrazole cycle and the quinoid bond system are of particular interest.

Antimicrobial and fungicidal activity studies were performed for newly synthesized naphthoquinonecontaining nitrogen derivatives. The scheme and method of synthesis are shown in Fig. 1 [20]. 
<smiles>Cc1cnn(C)c1</smiles>

a<smiles>Cc1ccn(C)n1</smiles>

b<smiles>Cc1cc([AlH2])n[nH]1</smiles>

C<smiles>[R]NC1=C(Cl)C(=O)c2ccccc2C1=O</smiles>

$3 a-d$

Fig. 1. Synthesis scheme of heterocyclic amino derivatives of 2,3-dichloro-1,4-naphthoquinone

The antimicrobial activity of the synthesized compounds 3a-d was studied by diffusion into agar on solid nutrient medium (beef agar extract for bacteria, wort agar for fungi). For all tested microorganisms, Petri dishes containing $20 \mathrm{ml}$ of culture medium were used. The inoculum (microbial loading - 109 cells (spores) / $1 \mathrm{ml}$ ) was applied to the surface of solidified media and Whatman No. 1 filtered disks (6 mm diameter) impregnated with the test compounds $(0.1$ and $0.5 \%)$ and placed on plates. The duration of bacterial incubation was $24 \mathrm{~h}$ at $35^{\circ} \mathrm{C}$ and the incubation of fungi $48-72 \mathrm{~h}$ at $28-30{ }^{\circ} \mathrm{C}$. The antimicrobial effect and the degree of activity of the tested compounds was evaluated by measuring the diameters of the zones of inhibition of growth of microorganisms (Table 1). Each experiment was repeated three times.
Table 1

Parameters of evaluation of results by the method of complex diffusion in agar

\begin{tabular}{|c|c|c|}
\hline No. & $\begin{array}{c}\text { The diameter of the zone } \\
\text { of inhibition of growth of } \\
\text { microorganisms, mm }\end{array}$ & $\begin{array}{c}\text { The degree of } \\
\text { sensitivity of } \\
\text { microorganisms }\end{array}$ \\
\hline 1. & $11-15$ & low sensitivity \\
\hline 2. & $16-25$ & sensitive \\
\hline 3. & $>25$ & highly sensitive \\
\hline
\end{tabular}

\section{Results of the research}

The main results of the study of fungicidal activity of compounds 3a-d by the method of diffusion of the substance into agar (method A) are shown in Table 2.

Table 2

Fungibactericidal activity of test compounds (method A)

\begin{tabular}{|c|c|c|c|c|c|c|}
\hline \multirow[t]{2}{*}{ Compound code } & \multirow[t]{2}{*}{ Concentration, $\%$} & \multicolumn{5}{|c|}{$\begin{array}{l}\text { The diameter of the zones of inhibition of growth of microorganisms, } \\
\mathrm{mm}\end{array}$} \\
\hline & & E.coli & S.aureus & M.luteum & C.tenuis & A.niger \\
\hline \multirow[t]{2}{*}{ 3a } & 0.5 & 0 & 15.4 & 13.0 & 24.0 & 20.0 \\
\hline & 0.1 & 0 & 7.4 & 0 & 20.0 & 17.0 \\
\hline \multirow[t]{2}{*}{$3 \mathbf{b}$} & 0.5 & 0 & 10.0 & 9.7 & 25.4 & 20.0 \\
\hline & 0.1 & 0 & 0 & 0 & 21.4 & 17.0 \\
\hline \multirow[t]{2}{*}{ 3c } & 0.5 & 0 & 0 & 10.0 & 0 & 0 \\
\hline & 0.1 & 0 & 0 & 7.0 & 0 & 0 \\
\hline \multirow[t]{2}{*}{$3 d$} & 0.5 & 0 & 10.4 & 15.0 & 0 & 10.0 \\
\hline & 0.1 & 0 & 7.0 & 10.0 & 0 & 8.0 \\
\hline $\mathbf{C}^{\mathbf{a}}$ & 0.1 & 14.0 & 15.0 & 18.0 & 19.0 & 20.0 \\
\hline
\end{tabular}

Note: $C^{a}:$ Vancomycin was used as a control in the antimicrobial activity tests of the synthesized compounds, and Nystatin was used in the antifungal activity tests

Determination of the minimum bacteriostatic concentration (MBC) or minimum fungistatic concentration (MFC) was performed by serial dilution method (method B). The test substance was dissolved in DMSO to achieve the desired concentration. Next, a certain amount of the solution of the substance was introduced into the nutrient medium (meat-peptone broth for bacteria and unhilled beer must for fungi).
The culture medium was inoculated with bacteria and fungi seed (microbial load of 106 cells (spores) $/ 1 \mathrm{ml}$ ). Seed tubes were kept in a thermostat at the appropriate temperature $\left(37{ }^{\circ} \mathrm{C}\right.$ for bacteria; $30{ }^{\circ} \mathrm{C}$ for fungi) for 24-72 hours. The results were evaluated in the presence or absence of growth of microorganisms (according to the degree of microbial turbidity of the nutrient medium). 
Bacterial test cultures were used to study the antimicrobial activity of the obtained compounds 3a-d: Escherichia coli, Staphylococcus aureus, Mycobacterium luteum and fungi: Candida tenuis, Aspergillus niger.

The gram-negative culture of $E$. coli bacteria was found to be resistant to the synthesized compounds 3a-3d at the tested concentration. The most active compounds against $C$.tenuis identified by the serial dilution method are compounds 3a $(\mathrm{MIC}=0.9 \mu \mathrm{g} / \mathrm{ml}, \mathrm{MFC}=1.9 \mu \mathrm{g} / \mathrm{ml})$ and $\mathbf{3 b}$ $(\mathrm{MIC}=7.8 \mu \mathrm{g} / \mathrm{ml}, \mathrm{MFC}=15.6 \mu \mathrm{g} / \mathrm{ml})($ Table 4$)$. The diameters of C.tenuis culture growth inhibition zones for these compounds at a concentration of $0.5 \%$ were $24.0 \mathrm{~mm}$ and $25.0 \mathrm{~mm}$, respectively, indicating the high sensitivity of this bacterial culture to the action of these compounds. This is higher than Nystatin. Compounds 3a, 3b, 3d showed moderate activity against the bacteria of the strain A.niger and S.aureus. Compared with Vancomycin, compound 3a at a concentration of $0.5 \%$ showed the same activity against $S$.aureus. The other compounds 3b-d are less active.

It was also found that all of our tested compounds 3a-d showed moderate activity against bacteria of the $M$. luteum strain.

The results of the initial experimental microbiological studies indicate the selective bacterio- and fungistatic activity of the synthesized compounds (Tab. 3).

Table 3

Indicators of minimum bactericidal concentration (MBC) and minimum inhibitory concentration (MIC) of compounds by serial dilution method (method B)

\begin{tabular}{|c|c|c|c|c|c|c|c|}
\hline \multirow{3}{*}{ No. } & \multirow{3}{*}{$\begin{array}{l}\text { Compound } \\
\text { code }\end{array}$} & \multicolumn{6}{|c|}{ Bacterial cultures } \\
\hline & & \multicolumn{2}{|c|}{ Escherichia coli } & \multicolumn{2}{|c|}{ Staphylococcus aureus } & \multicolumn{2}{|c|}{ Mycobacterium luteum } \\
\hline & & $\begin{array}{l}\mathrm{MIC}, \\
\mu \mathrm{g} / \mathrm{ml}\end{array}$ & $\begin{array}{l}\mathrm{MBC}, \\
\mu \mathrm{g} / \mathrm{ml}\end{array}$ & $\begin{array}{l}\mathrm{MIC}, \\
\mu \mathrm{g} / \mathrm{ml}\end{array}$ & $\begin{array}{l}\mathrm{MBC}, \\
\mu \mathrm{g} / \mathrm{ml}\end{array}$ & $\begin{array}{c}\mathrm{MIC}, \\
\mu \mathrm{g} / \mathrm{ml}\end{array}$ & $\begin{array}{l}\mathrm{MBC}, \\
\mu \mathrm{g} / \mathrm{ml}\end{array}$ \\
\hline 1. & $3 a$ & + & + & 31.2 & 62.5 & 7.8 & 15.6 \\
\hline 2. & 3b & + & + & 31.2 & 62.5 & 7.8 & 15.6 \\
\hline 3. & $3 c$ & + & + & + & + & 31.2 & 125.0 \\
\hline 4. & 3d & + & + & 125.0 & 250.0 & 15.6 & 31.2 \\
\hline
\end{tabular}

Table 4

Indicators of minimum fungicidal concentration (MFC) and minimum inhibitory concentration (MIC) of compounds by serial dilution method (method B)

\begin{tabular}{|c|c|c|c|c|c|}
\hline \multirow{3}{*}{ No. } & \multirow{3}{*}{ Compound cod } & \multicolumn{4}{|c|}{ Bacterial cultures } \\
\hline & & \multicolumn{2}{|c|}{ Candida tenuis } & \multicolumn{2}{|c|}{ Aspergillus niger } \\
\hline & & $\begin{array}{l}\text { MIC, } \\
\mu \mathrm{g} / \mathrm{ml}\end{array}$ & $\begin{array}{l}\text { MFC, } \\
\mu \mathrm{g} / \mathrm{ml}\end{array}$ & $\begin{array}{l}\mathrm{MIC}, \\
\mu \mathrm{g} / \mathrm{ml}\end{array}$ & $\begin{array}{l}\text { MFC, } \\
\mu \mathrm{g} / \mathrm{ml}\end{array}$ \\
\hline 1. & $3 \mathbf{a}$ & 0.9 & 1.9 & 0.9 & 15.6 \\
\hline 2. & $3 \mathbf{b}$ & 7.8 & 15.6 & 7.8 & 31.2 \\
\hline 3. & $3 c$ & + & + & + & + \\
\hline 4. & 3d & 250.0 & 500.0 & 62.5 & 250.0 \\
\hline
\end{tabular}

Note: «+»-no biocidal effect was observed in the tested concentrations (microbial growth was observed)

The rodent acute toxicity assessment is an extremely important feature in the development of new drugs. However, given the relatively high cost of such experimental studies and ethical considerations, we used the prediction of acute toxicity of aminopyrazole naphthoquinonederivatives to rats using a free, accessible web service (http://www.pharmaexpert.ru/GUSAR/ AcuToxPredict/) for various routes of administration of substances (intraperitoneal, intravenous, oral and subcutaneous). This is a method for modelling acute toxicity for QSAR rodents, implemented in GUSAR software [19]. Acute toxicity is an important adverse effect (or death) that occurs shortly after a single dose of the substance has started. The $\mathrm{LD}_{50}$ value is one of the important characteristics of acute toxicity corresponding to a dose that causes $50 \%$ mortality within 24 hours after administration of the substance. Acute toxicity, determined by external, oral or inhalation administration of the substance, is an important parameter for assessing overall toxicological risk, whereas acute toxicity for intra-intravenous and intravenous substance administration is an important parameter for drug development. There is a large amount of data in the literature and databases on the $\mathrm{LD}_{50}$ of different compounds for rats, which enables the evaluation of $\mathrm{LD}_{50}$ in silico using different QSAR methods [22]. The results of the studies are presented in Table 5. The results of the acute toxicity prediction show that the synthesized aminopyrazole derivatives of naphthoquinone can obviously be considered as low toxicity drugs ( 4,5 class toxicity). In addition, the predicted data indicate that compound $\mathbf{3 c}$ is non-toxic in the intraperitoneal route of administration, and compound 3d is non-toxic in the subcutaneous route of administration. 
Table 5

Predicted acute toxicity of synthesized aminopyrazole naphthoquinone derivatives for rats

\begin{tabular}{|c|c|c|c|c|c|c|c|c|}
\hline \multirow[b]{2}{*}{$\begin{array}{l}\text { Com- } \\
\text { pound } \\
\text { No. }\end{array}$} & \multicolumn{2}{|c|}{$\begin{array}{l}\text { Intraperitoneal route of } \\
\text { administration }\end{array}$} & \multicolumn{2}{|c|}{$\begin{array}{c}\text { Intravenous route of administra- } \\
\text { tion } \\
\end{array}$} & \multicolumn{2}{|c|}{ Oral route of administration } & \multicolumn{2}{|c|}{$\begin{array}{c}\text { Subcutaneous route of admin- } \\
\text { istration }\end{array}$} \\
\hline & $\begin{array}{c}\mathrm{LD}_{50} \\
(\mathrm{mg} / \mathrm{kg})\end{array}$ & $\begin{array}{l}\text { Classification } \\
\text { of substance } \\
\text { toxicity } *\end{array}$ & $\mathrm{LD}_{50}(\mathrm{mg} / \mathrm{kg})$ & $\begin{array}{l}\text { Classification of } \\
\text { ubstance toxicity * }\end{array}$ & $\mathrm{LD}_{50}(\mathrm{mg} / \mathrm{kg})$ & $\begin{array}{l}\text { Classifica- } \\
\text { tion of sub- } \\
\text { stance tox- } \\
\text { icity * }\end{array}$ & $\mathrm{LD}_{50}(\mathrm{mg} / \mathrm{kg})$ & $\begin{array}{c}\text { Classification } \\
\text { of substance } \\
\text { toxicity* }\end{array}$ \\
\hline $3 a$ & 675.300 & Class 5 & 108.700 & Class 4 & 730.700 & Class 4 & 727.300 & Class 4 \\
\hline 3b & 760.600 & Class 5 & 113.600 & Class 4 & 672.200 & Class 4 & 753.600 & Class 4 \\
\hline $3 c$ & 1282.000 & Non Toxic & 86.480 & Class 4 & 1479.000 & Class 4 & 536.500 & Class 4 \\
\hline 3d & 1095.000 & Class 5 & 94.950 & Class 4 & 1537.000 & Class 4 & 2590.00 & Non Toxic \\
\hline
\end{tabular}

Therefore, the initial screening of the biological activity and toxicity of the synthesized compounds indicate the high feasibility of further experimental preclinical studies in order to find new effective drug substances.

\section{Discussion of the results}

As a result of a study of the fungicidal activity of aminopyrazole naphthoquinone derivatives by methods $\mathrm{A}$ and $\mathrm{B}$, it was found that the most active among the tested compounds is 2-chloro-3-((1-methyl-1H-pyrazol-4yl)amino) naphthalene-1,4-dione $3 \mathbf{a}$ and 2-chloro-3-((1methyl-1H-pyrazol-3-yl)amino) naphthalene-1,4-dione $\mathbf{3 b}$, which exhibit a wide range of fungicidal activity and moderate bacterial culture activity of $M$. luteum strain. Ethyl-4(((3-chloro-1,4-dioxo-1,4-dihydrona-phthalen-2-yl)amino)1-phenyl-1H-pyrazole-3-carboxy-late 3d exhibits little fungicidal activity against test cultures, except $E$. coli, whose growth is not affected by any of our compounds. Moderate activity against bacteria of the $M$. luteum strain exhibits 2-chloro-3-((3-(p-tolyl) -1H-pyrazol-5-yl) amino) naphthalene-1,4-dione 3c.

When comparing the test compounds with the standards in the diameter of the zones of growth inhibition of microorganisms (Tab. 2) we found that compounds $\mathbf{3 a}$ and $\mathbf{3 b}$ have slightly higher fungicidal activity than Nystatin. The antimicrobial activity of compound 3a is similar to Vancomycin.

Conducted in silico toxicity spectrum studies of the compounds 3a - 3d under study indicate their predicted low toxicity. To confirm the predicted low toxicity of heterocyclic naphthoquinone derivatives, it is advisable to conduct further in vivo studies.

When comparing the fungicidal activity of the compounds studied by us with those of other naphthoquinone S-derivatives [2]: 2-chloro-3-\{[3-(2-methylfuran-3yl)-5-thioxo-1,5-dihydro-4H-1,2,4-triazol-4-yl] amino naphthalene-1,4-dione, 2-\{[4-amino-5-(2-methylfuran-3-yl) -4H-1,2,4-triazol-3-yl]sulfanyl\}-3-chloronaphthalene-1,4dione and 2-chloro-3-\{[3-(3-methylfuran-2-yl)-5-thioxo1,5-dihydro-4H-1,2,4-triazol-4-yl]amino naphthalene-1 by 4-dione, it was found that S-substituted naphthoquinones exhibit high activity against $S$. aureus strain and low against $C$.tenuis and $M$. luteum strains. N-substituted naphthoquinones, on the contrary, are highly active against C.tenuis and M.luteum strains. This proves the relationship between the structure of the compounds and their activity.

Study limitations. When developing new drugs, it is important to assess their acute toxicity on rodents. However, such experimental studies are quite expensive, and they are constantly criticized for ethical reasons.

Prospects for further research. Therefore, the results of our studies indicate the need for further pharmacological screening of aminopyrazole derivatives of naphthoquinone in order to create new low-toxic antimicrobial and fungicidal agents based on them.

Given the informative nature of the screening results, it is possible to continue studying their activity against a larger sample of clinical strains of microorganisms. The properties of the basic structures thus identified need to be further optimized by the synthesis and investigation of a large number of their analogues.

\section{Conclusions}

The antimicrobial activity of aminopyrazole naphthoquinone derivatives was investigated and found that 2-chloro-3-((1-methyl-1H-pyrazol-4-yl)amino) naphthalene-1,4-dione (3a) and 2-chloro-3-((1-methyl-1Hpyrazol-3-yl)amino) naphthalene-1,4-dione (3b) exhibit high antimicrobial activity against Candida tenuis test culture. All the compounds tested do not affect the growth of bacteria of the genus Escherichia coli. The results of the initial experimental microbiological studies indicate the selective bacterio- and fungistatic activity of the nitrogen-containing heterocyclic naphthoquinone derivatives. The test compounds can be attributed to lowtoxic drugs, and therefore it is advisable to conduct further experimental studies of these substances.

\section{Conflict of interests}

Authors declare no conflict of interests

\section{References}

1. Janeczko, M., Demchuk, O. M., Strzelecka, D., Kubiński, K., Masłyk, M. (2016). New family of antimicrobial agents derived from 1,4-naphthoquinone. European Journal of Medicinal Chemistry, 124, 1019-1025. doi: http://doi.org/10.1016/ j.ejmech.2016.10.034

2. Shakh, Y. U., Romanenko, I., Slesarchuk, M., Syngaevsky, V., Kovalchuk, O., Bolibrukh, K. et. al. (2017). Synthesis and Antimicrobial Activity of 1,4-Naphthoquinones Derivatives with $\lceil 1,2,4]$-Triazole-3-thione Substitution. Indian Journal of Pharmaceutical Sciences, 79 (4), 650-654. doi: http://doi.org/10.4172/pharmaceutical-sciences.1000275

3. Wellington, K. W., Kolesnikova, N. I., Nyoka, N. B. P., McGaw, L. J. (2018). Investigation of the antimicrobial and anticancer activity of aminonaphthoquinones. Drug Development Research, 80 (1), 138-146. doi: http://doi.org/10.1002/ddr.21477 
4. Wellington, K. W. (2015). Understanding cancer and the anticancer activities of naphthoquinones - a review. RSC Advances, 5 (26), 20309-20338. doi: http://doi.org/10.1039/c4ra13547d

5. Ravichandiran, P., Subramaniyan, S. A., Kim, S. Y., Kim, J. S., Park, B. H., Shim, K. S., Yoo, D. J. (2019). Synthesis and Anticancer Evaluation of 1, 4 Naphthoquinone Derivatives Containing a Phenylaminosulfanyl Moiety. ChemMedChem, 14 (5), 532-544. doi: http://doi.org/10.1002/cmdc.201800749

6. Xu, K., Xiao, Z., Tang, Y. B., Huang, L., Chen, C.-H., Ohkoshi, E., Lee, K.-H. (2012). Design and synthesis of naphthoquinone derivatives as antiproliferative agents and 20S proteasome inhibitors. Bioorganic \& Medicinal Chemistry Letters, 22 (8), 2772-2774. doi: http://doi.org/10.1016/j.bmcl.2012.02.086

7. López López, L. I., Flores, N., Daniel, S., Silva Belmares, S. Y., Sáenz Galindo, A. (2014). Naphthoquinones: biological properties and synthesis of lawsone and derivatives-a structured review. Vitae, 21 (3), 248-258.

8. El-Naijar, N., Gali-Muhtasib, H., Ketola, R. A., Vuorela, P., Urtti, A., Vuorela, H. (2011). The chemical and biological activities of quinones: overview and implications in analytical detection. Phytochemistry Reviews, 10 (3), 353-370. doi: http://doi.org/10.1007/s11101-011-9209-1

9. Liu, F. (2012). Synthesis of natural products and small molecules using quinones. doi: http://doi.org/10.31274/etd-180810-2332

10. Ibis, C., Sahinler Ayla, S., Yavuz, S. (2019). Reactions of quinones with some aryl phenols and synthesis of new quinone derivatives. Synthetic Communications, 49 (2), 202-211. doi: http://doi.org/10.1080/00397911.2018.1546403

11. Ravichandiran, P., Kannan, R., Ramasubbu, A., Muthusubramanian, S., Samuel, V. K. (2016). Green synthesis of 1,4quinone derivatives and evaluation of their fluorescent and electrochemical properties. Journal of Saudi Chemical Society, 20, S93S99. doi: http://doi.org/10.1016/j.jscs.2012.09.011

12. De Moraes, T., Filha, M., Camara, C., Silva, T., Soares, B., Bomfim, I. et. al. (2014). Synthesis and Cytotoxic Evaluation of a Series of 2-Amino-Naphthoquinones against Human Cancer Cells. Molecules, 19 (9), 13188-13199. doi: http://doi.org/10.3390/ molecules 190913188

13. Sieveking, I., Thomas, P., Estévez, J. C., Quiñones, N., Cuéllar, M. A., Villena, J. et. al. (2014). 2Phenylaminonaphthoquinones and related compounds: Synthesis, trypanocidal and cytotoxic activities. Bioorganic \& Medicinal Chemistry, 22 (17), 4609-4620. doi: http://doi.org/10.1016/j.bmc.2014.07.030

14. Ansari, A., Ali, A., Asif, M., Shamsuzzaman, S. (2017). Review: biologically active pyrazole derivatives. New Journal of Chemistry, 41 (1), 16-41. doi: http://doi.org/10.1039/c6nj03181a

15. Jahangir, A. Md. et. al. (2015). A review on pyrazole chemical entity and biological activity. International Journal of Pharmaceutical Sciences and Research, 6, 1433-1442.

16. El Shehry, M. F., Ghorab, M. M., Abbas, S. Y., Fayed, E. A., Shedid, S. A., Ammar, Y. A. (2018). Quinoline derivatives bearing pyrazole moiety: Synthesis and biological evaluation as possible antibacterial and antifungal agents. European Journal of Medicinal Chemistry, 143, 1463-1473. doi: http://doi.org/10.1016/j.ejmech.2017.10.046

17. Rizk, H. F., Ibrahim, S. A., El-Borai, M. A. (2015). Synthesis, fastness properties, color assessment and antimicrobial activity of some azo reactive dyes having pyrazole moiety. Dyes and Pigments, 112, 86-92. doi: http://doi.org/10.1016/ j.dyepig.2014.06.026

18. Coyle, M. B. (2005). Manual of Antimicrobial Susceptibility Testing. American Society for Microbiology. Washington: American Society for Microbiology, 236.

19. McFarland, J. (1907). Nephelometer: An Instrument for Estimating the Number of Bacteria in Suspensions Used for Calculating the Opsonic Index and for Vaccines. Journal of the American Medical Association, 49 (14), 1176-1178. doi: http://doi.org/10.1001/jama.1907.25320140022001f

20. Polish, N. V., Marintsova, N. G., Zhurakhivska, L. R., Novikov, V. P., Vovk, M. V. (2019). Synthesis and prediction of the biological activity of heterocyclic n-derivatives naphthoquinone. Chemistry, Technology and Application of Substances, 2 (1), 69-75. doi: http://doi.org/10.23939/ctas2019.01.069

21. Lagunin, A., Zakharov, A., Filimonov, D., Poroikov, V. (2011). QSAR Modelling of Rat Acute Toxicity on the Basis of PASS Prediction. Molecular Informatics, 30 (2-3), 241-250. doi: http://doi.org/10.1002/minf.201000151

Received date 22.11.2019

Accepted date 19.12.2019

Published date 30.12.2019

Nataliia Polish, Postgraduate Student, Department of Technology Biologically Compounds, Pharmacy and Biotechnology, Lviv Polytechnic National University, St. Bandery str., 12, Lviv, Ukraine, 79013. E-mail: polishn@ukr.net

Olha Voitsakhivska, Department of Technology Biologically Compounds, Pharmacy and Biotechnology, Lviv Polytechnic National University, St. Bandery str., 12, Lviv, Ukraine, 79013. E-mail: olyavoitsahivska@gmail.com

Nataliia Marintsova, PhD, Associate Professor, Department of Technology Biologically Compounds, Pharmacy and Biotechnology, Lviv Polytechnic National University, St. Bandery str., 12, Lviv, Ukraine, 79013

E-mail: nmarintsova@gmail.com

Lesya Zhurakhivska, PhD, Associate Professor, Department of Technology Biologically Compounds, Pharmacy and Biotechnology, Lviv Polytechnic National University, St. Bandery str., 12, Lviv, Ukraine, 79013 E-mail: zhurakhivska@ukr.net

Volodymyr Novikov, Doctor of Chemical Sciences, Professor, Department of Technology Biologically Compounds, Pharmacy and Biotechnology, Lviv Polytechnic National University, St. Bandery str., 12, Lviv, Ukraine, 79013. E-mail: volodymyr.p.novikov@lpnu.ua

Bohza Serhii, Doctor of Chemical Sciences, Senior Researcher, Institute of Organic Chemistry of the National Academy of Sciences of Ukraine, Murmanska str., 5, Kyiv, Ukraine, 02660. E-mail: serge-bogza@yandex.ua 